\title{
Borderline Ovarian Mucinous Tumor/Atypical Proliferative Ovarian Mucinous Tumor with Microinvasion
}

National Cancer Institute

\section{Source}

National Cancer Institute. Borderline Ovarian Mucinous Tumor/Atypical Proliferative

Ovarian Mucinous Tumor with Microinvasion. NCI Thesaurus. Code C159311.

A low grade ovarian epithelial neoplasm characterized by the presence of neoplastic mucinous epithelial cells, atypia, and microinvasion of the ovarian stroma. 